\title{
HISTOLOGICAL AND IMUNOHISTOCHEMICAL STUDY OF THE EFFECT OF BONE MARROW DERIVED STEM CELLS ON AGE CHANGES OF PULP IN ALBINO RATS
}

\author{
Tahany Haggag *
}

\begin{abstract}
Background: Aging is a complex natural process including every molecule, cell and organ in the body. In its broadest mean, aging refers to changes that occur during the life span. Some of these changes are not harmful while other increase the risk of diseases.

Aim: The purpose of the current study was to investigate the histological and immunohistochemical effects of bone marrow derived stem cells on age changes of pulp in albino rats.

Material and methods: Forty five (fifteen adults aging six months and thirty olds aging fifteen months) male albino rats were divided into three equal groups. Group I (Adult group) that get infused with saline intravenously to serve as control group, group II (old age group) which also get infused with saline intravenously and group III (old age injected by stem cells). The source of stem cells was from additional fifteen albino rats six weeks old which will be used for isolation and culture of bone marrow stem cells.
\end{abstract}

Results: Old age group revealed sever histological alterations and negative Ki67 expression compared to control group while old group injected by stem cells revealed histological reorganizations of the pulp cells and mild to moderate Ki67 expression that was nearly similar to control group.

Conclusion: Intravenous injection of bone marrow mesenchymal stem cells improved the histological features of the pulp compared to old group and also it had a positive proliferating effect by the enhanced expression of Ki67.

KEYWORDS: Aging; Dental pulp; Mesenchymal Stem cell; Rats.

\section{INTRODUCTION}

The dental pulp is a mesenchymal connective tissue situated in a cavity in the central area of the tooth - the pulp chamber (cavum dentis) and includes the coronal cavity (cavum coronale) and continues in the roots of the teeth with the radicular channel (canalis radicis dentis); they communicate with the external environment at the apex level through the

\footnotetext{
* Lecturer of Oral Biology Department, Faculty of Oral and Dental Medicine, Cairo University. Egypt
} 
apical foramen (foramen apices dentis) Bratu D., Românu M (1998). The expression "growing long in the tooth" has been ubiquitously used to describe the process of getting old. However, changes occur naturally in the mouth with altered function and time. Teeth in healthy aging exhibit change in both visual appearance and molecular makeup. The pulp exhibits numerous age changes such as decreases in its reparative capabilities (Murray PE, Stanley HR, Matthews JB, et al 2002). The pulpal blood flow declines in older adults due to a decrease in the number of blood vessels and an increase in calcified tissues in tooth pulp (Ikawa M, Komatsu H, Ikawa $\mathbf{K}$, et al 2003). In addition, magnetic resonance imaging (MRI) findings suggest a decline in pulp signal intensity (Kress B, Buhl Y, Hahnel S, et al. 2007). The results of these physiologic changes along with increased dentinal thickness decrease pulpal resiliency and its ability to sense insult, so that one of most important point is to try to treat and minimize these age changes and maintain the normal pulp vitality.

In recent year, there has been continuing interest in both the biology and potential therapeutic applications of the adult stem like cells from bone marrow, referred to as either mesenchymal stem cells or marrow stromal cells (MSCs) (Caplan AI. 2003, Colter DC, Sekiya I, Prockop DJ.2001). Stemness is the capability of undifferentiated cells to undergo an indefinite number of replications (self-renewal) and give rise to specialized cells (differentiation). Therefore, stem cells differ from other types of cells in the body because they are capable of sustaining self-renewal, are unspecialized, and can give rise to differentiated cell types. Differentiation can be recognized by a change in the morphology of the cell and by the detection of tissue-specific proteins (Weissman IL 2002). Mesenchymal stem cells (MSCs) are classically defined as adherent, non-hematopoietic cells expressing the surface markers CD90, CD105, and CD73, and lacking the expression of CD14, CD34, and CD45. The cells also have the capacity to differentiate into adipocytes, chondrocytes and osteocytes in vitro after treatment with differentiation inducing agents (Prockop DJ 1997). Although early studies in the late 1960s initially identified MSCs in the bone marrow (Friedenstein AJ et al., 1968) more recent studies have reported these cells can be purified from various tissues such as adipose (Zannettino ACW et al. 2008), heart (Hoogduijn MJ. et al., 2007), dental pulp ( Jo YY.2007), peripheral blood (He Q, Wan C, Li G 2007) and more recently menstrual blood (Hida $\mathbf{N}$ et al., 2008 and Patel AN et al., 2008) and chorionic villi (Yang ZX, et al., 2013). MSCs from human and rat bone marrow have been the most extensively characterized, in part because they are relatively easy to isolate by their adherence to plastic and can be extensively expanded in culture. Also, the human and rat MSCs can differentiate into multiple cell phenotypes, including bone, fat, cartilage, muscle, epithelium, and early neural progenitors (Javazon $\mathbf{E}$ et al., 2001 and Sekiya I et al., 2002). Bone marrowderived cells (BMCs) have been suggested as an easy, accessible source for multipotent stem cells that could potentially transdifferentiate and/or repair other non hematopoietic organs (Lagasse, E. et al., 2000, Nishida, M.et al., 2004 and Couzin, J. 2006). By culturing, they may be expanded many fold to provide nearly unlimited starting material for cellular therapeutic applications. Mesenchymal bone marrow stem cells (MBM-SCs) can also be isolated by means of minimally invasive procedures from $\mathrm{BM}$, requires only a small amount of tissue from the patient and this approach can restore bone defects without incurring donor site morbidity (Pittenger MF, Mosca JD, Mcintosh KR. 2000, and Jäger M. et al., 2009). As regarding immunohistochemistry, Scholzen and Gerdens 2000 claimed that the Ki67 antigen is a classic marker of cellular proliferation and has found wide spread application in diagnostic, research and drug discovery applications. Ki67 antigen is preferentially expressed during late 
G 1, S, G 2 and M phase of cell cycle, while resting non cycling cells ( $\mathrm{G} 0$ phase) lack Ki67 expression. Thus Ki67 is commonly used as a proliferating marker. Because of the lack of any consensus among the researchers, further studies are necessary to elucidate the relation between the bone marrow mesenchymal stem cell and aging. Therefore, in the present study we aimed to investigate the effects of bone marrow mesenchymal stem cell histologically and immunohistochemically on age changes of the pulp in rats.

\section{MATERIALS AND METHODS}

Forty five (fifteen adults aging six months and thirty olds aging fifteen months) male albino rats, weighing 100-150 grams each, will be obtained from the "Animal Research center" Faculty of medicine, Cairo University, will be used in the study. The rats will be housed in specially designed wire cages and will be maintained under good ventilation. They will be fed standard laboratory diet and supplied drinking water ad-libitum.

An additional fifteen albino rats six weeks old will be used for isolation and culture of bone marrow stem cells at the Biochemistry and Microbiology Unit, Faculty of Medicine, Cairo University.-

The forty five rats were divided equally into three groups, fifteen rats for each group. Group I (Adult group) consists of fifteen adults albino rats (six months old) and get infused with saline intravenously to serve as control group, Group II (Old age group) consists of fifteen albino rats (fifteen months old) to get infused with saline intravenously and Group III ( old age injected by stem cells ) consists of fifteen albino rats (fifteen months old) to be subjected to intravenous infusion by mesenchymal stem cells. The cell numbers were calculated by the hemocytometer. For I.V. administration, $1.5 \times 10^{3}-10^{6}$ cells/rat in $0.2 \mathrm{ml}$ phosphate buffer saline was slowly injected into one tail vein of the anesthetized rat over a 2-minute period using a 22-gauge needle (Guo et al., 2011), to study the effect of injection of bone marrow derived stem cells on age changes of pulp in albino rats.

\section{Preparation of bone marrow-derived mesenchy- mal stem cells (MSCs)}

Bone marrow harvested by flushing the tibiae and femurs of the 6 week-old male albino rats with Dulbecco's modified Eagle's medium (DMEM, GIBCO/BRL) supplemented with $10 \%$ fetal bovine serum (GIBCO/BRL). Nucleated cells were isolated with a density gradient [Fico11/Paque (Pharmacial)] and esuspended in complete culture medium supplemented with $1 \%$ penicillin-streptomycin (GIBCO/BRL).

Cells were incubated at $37^{\circ} \mathrm{C}$ in $5 \%$ humidified $\mathrm{CO}_{2}$ for 12-14 days as primary culture or upon formation of larger colonies. When large colonies develop (80-90\% confluence), cultures were washed twice with phosphate buffer saline (PBS) and the cells were trypsinized with $0.25 \%$ trypsin in $1 \mathrm{~mm}$ EDTA (GIBCO/BRL) for $5 \mathrm{~min}$ at $37^{\circ}$ C . After centrifugation, cells will be resuspended with phosphate buffer saline. MSCs in culture were characterized by their adhesiveness and fusiform shape and by detection of CD29 one of the surface marker for MSCs by RT-PCR.

\section{Specimen Preparation and Histopathological Examination}

Each mandible was dissected free and soft tissue was immediately removed. The right and left mandibular segments were dissected and the specimens were processed. Specimens were fixed in neutral buffered formaldehyde solution for 72 hours. The samples were then decalcified by immersing the specimen in decalcifying working solution of EDTA for 30 days. The decalcified specimen was then dehydrated with graded ethyl alcohol washes $(50 \%, 70 \%, 85 \%$ then $100 \%)$ and imbedded in paraffin wax with an orientation that 
provide sectioning along the sagittal plane of the jaw. Sections of $4 \mu \mathrm{m}$ thickness were cut and were subjected to the following

1- Stained with hematoxylin and eosin for routine light microscopic examination.

2- Immunohistochemical evaluation using Ki67 markers.

\section{RESULTS}

\section{Histological results}

\section{Control group (group I)}

Light microscopic examination of pulp showed that the pulp revealed a homogeneity in its cells, intercellular substance, fiber elements and blood vessels. On the periphery of the pulp, adjacent to the calcified dentin, predentin is present . Next to the predentin situated the palisade of columnar odontoblast cells. Central to the odontoblasts is the subodontoblastic layer, termed the cell-free zone which is sometimes indistinct or absent. Deep to the odontoblastic layer is the cell-rich zone, which blends in turn with the dominant pulp core with normal condensation of collagen fibers (Figure 1).

\section{Group II}

Microscopic examination of the pulp of old age group revealed that, formation of secondary dentine, odontoblasts lost its palisade arrangement and appeared atrophied as well as formation of pulp stones. Multiple dilated and congested blood vessel were observed (Figure 2).

In another specimens showed that odontoblasts are severely affected, atrophied and shirked with wide separation between the pulp core and the periphery of the pulp with sever condensation of collagen fibers (Figure 3). Other features of age changes were seen in figure $\mathbf{4}$ as area of nearly completely destructed odontoblasts, large pulp stone, congested blood vessels and extravasated red blood cells.

\section{Group III}

Microscopic examination of the old group injected with mesenchymal stem cells showed that nearly normal histological structures as pulp cells returned to their normal organization surrounded by loosely arranged collagen fibers and thin walled normally sized blood vessels (Figs 5\&6).

\section{Immunohistochemical results}

Using the immunohistochemical labeling, we have assayed the expression of Ki67 in cells of the dental pulp in all groups.

The present study showed that, group I (control group) revealed mild to moderate expression of Ki67 in nuclei of odontoblasts and endothelium lining of the blood vessels while group II (aged group) showed nearly negative expression of Ki67. As regarding as group III (aged group injected with mesenchymal stem cells) revealed nearly the same mild to moderate immunoexpression of Ki67 as control group.

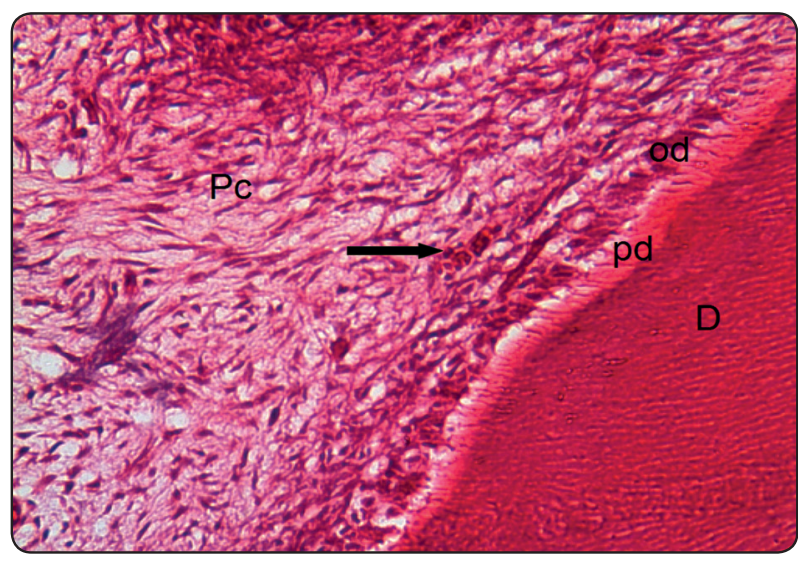

Fig. (1) A photomicrograph of pulp insitu of group I (control group) showing normal histological structures of dentin (D), predentin (Pd), odontoblasts (Od), blood vessel (arrow) and pulp core (Pc). (H\&E x 400) 

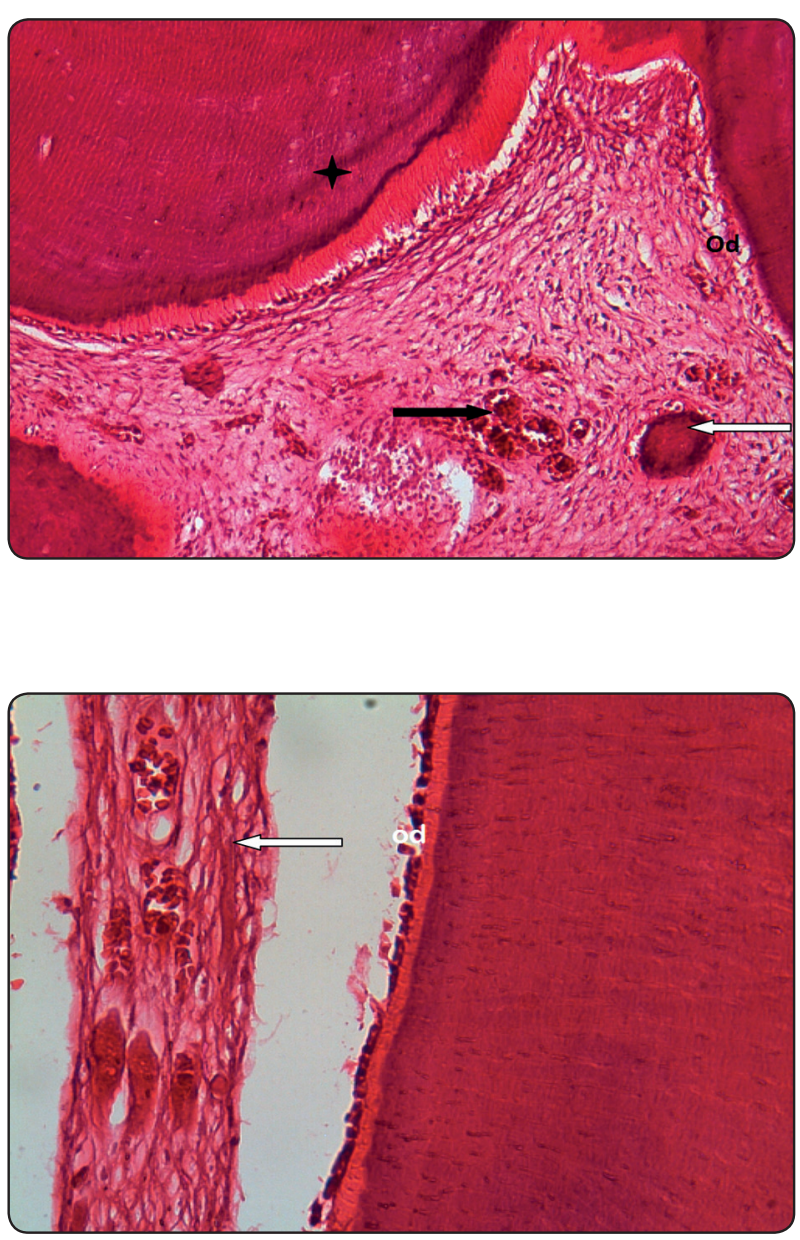

Fig. (3) A photomicrograph of group II showing sever atrophy of odontoblasts (Od) and condensation of collagen fibers (arrow ). (H\&E x 400)

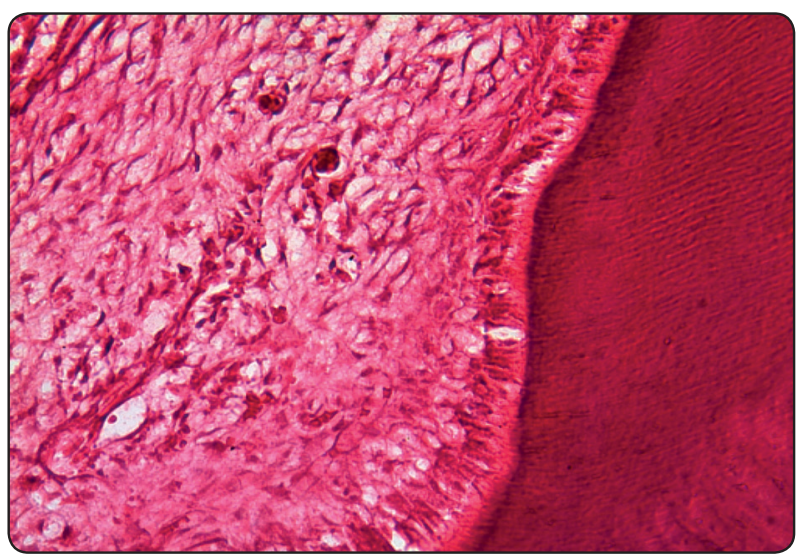

Fig. (5) A photomicrograph of group III showing nearly normal histological structures. (H\&E x 400)
Fig. (2) A photomicrograph of group II showing age changes features as formation of secondary dentin with apparent line of demarcation between primary and secondary dentin (star), disorientation and atrophy of odontoblasts (Od), pulp calcification (white arrow) and numerous congested blood vessels (black arrow). (H\&E x 200)

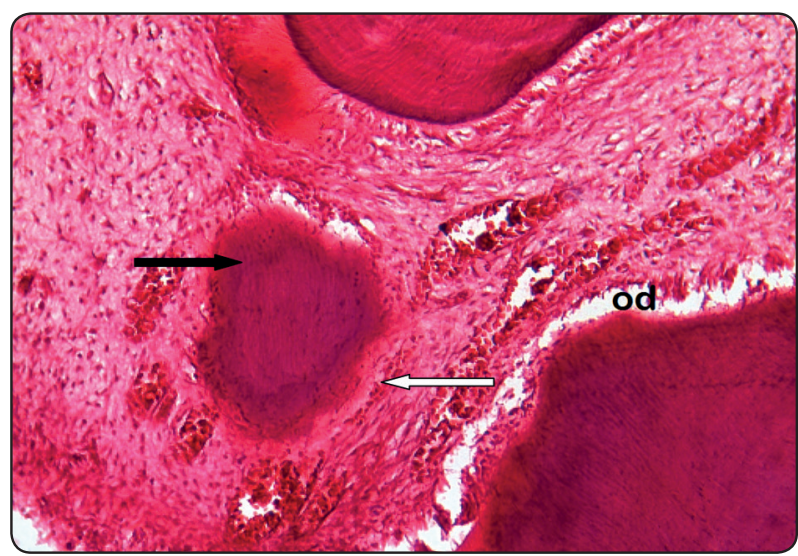

Fig. (4) A photomicrograph of group II showing area of completely degenerated odontoblasts (od), congested blood vessels with area of hemorrhage ( white arrow) and large pup stone (black arrow). (H\&E x 200)

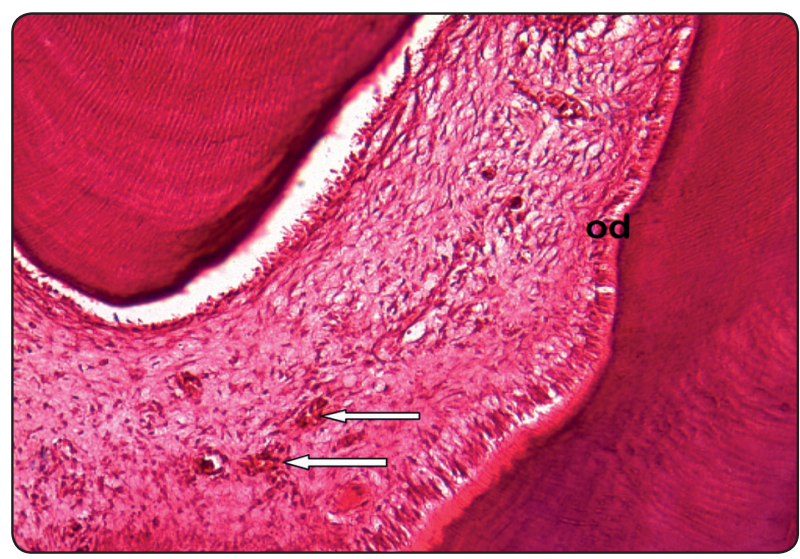

Fig. (6) A photomicrograph of group III showing reorganized odontoblasts and normal sized blood vessels(arrow). (H\&E x 200) 


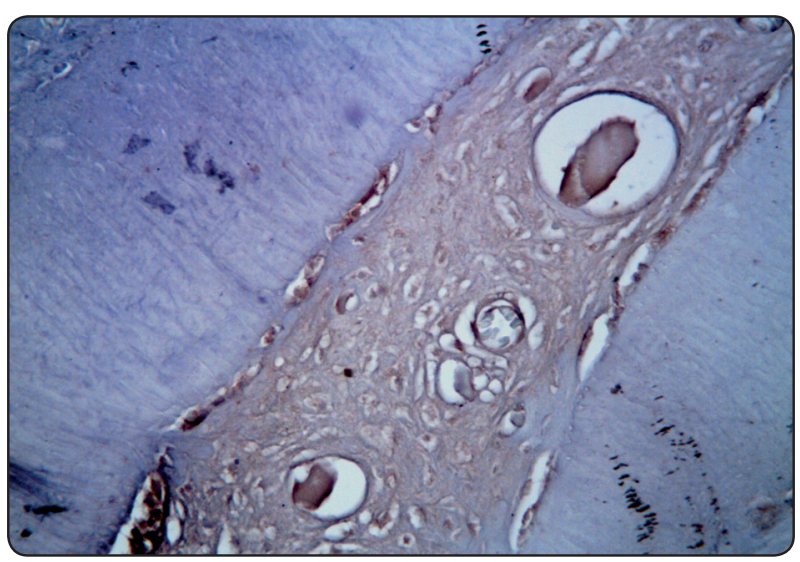

Fig. (7) A photomicrograph of Ki67 immunostaining of pulp of group I showing positive control group with mild to moderate expression of Ki67. (Ki67 x400)

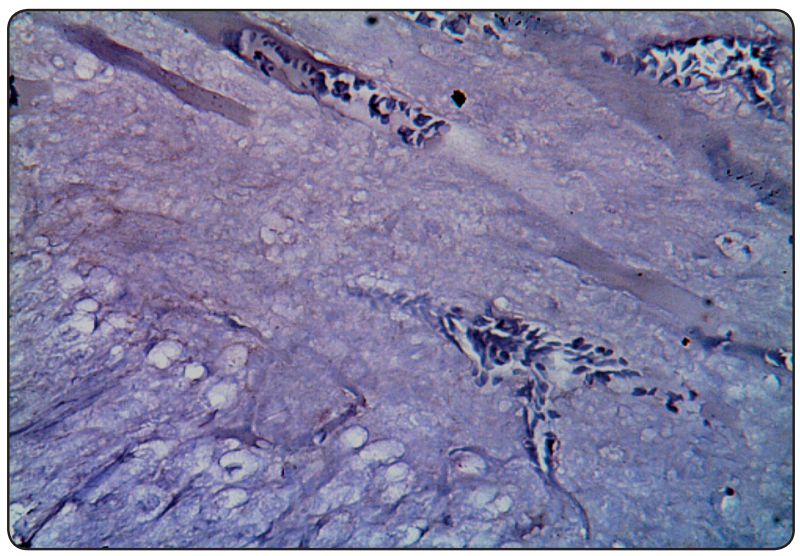

Fig.(8) A photomicrograph of Ki67 immunoexpression of group II showing nearly negative expression of Ki67 in aged pulp tissue. (Ki67 x400)

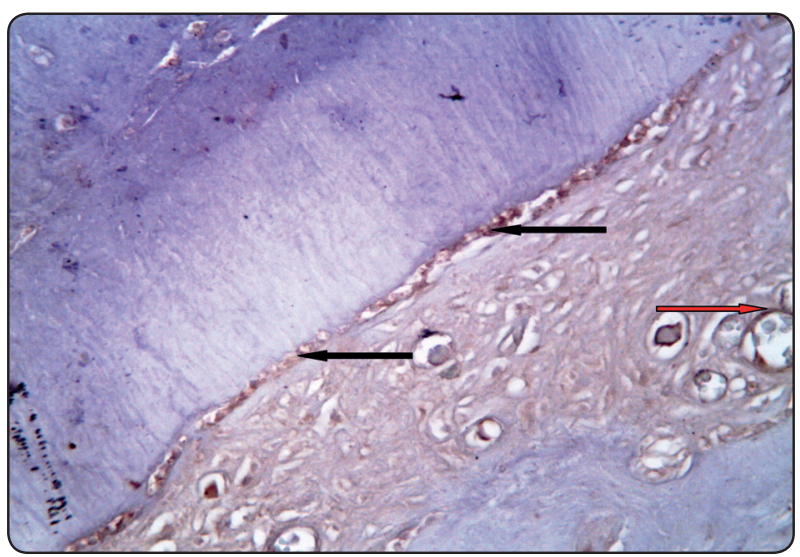

Fig.(9) A photomicrograph of group III showing sign of proliferation presented by mild to moderate expression of Ki67 immunostaining in nuclei of odontoblasts (black arrow) and endothelium of the blood vessels (red arrow) . (Ki67 x 400)

\section{DISCUSSION}

The emergency field of regenerative medicine holds the promise of treating a variety of degenerative and age related changes where no specific or effective treatment is currently available. Stem cell in general and mesenchymal stem cell in particular with their versatile growth and differential potential are ideal candidates for use in regenerative medicine protocol. So the current study was carried out to evaluate histologically and immunohistochemically the effect of bone marrow mesenchymal stem cells on age changes of pulp in albino rats. Light microscopic examination of $\mathrm{Hx} \& \mathrm{E}$ stained sections of the pulp revealed several histological alterations when comparing the results of adult rats group I, which appeared with its normal histological structures while group II (old age rats), there were loss of palisade arrangement, atrophy, degeneration and total destruction of odontoblasts. Formation of secondary dentin with apparent line of demarcation separating the primary dentin from secondary dentin was observed. These results were in agreement with those found by Berkovitz et al., (1992) and Solheim, (1992) who reported that secondary dentin is laid down at the pulpal end of the primary dentin with age and consequently the pulp cavity decrease in size. Our results revealed formation of pulp stones of variable sizes. These result coincides with the results obtained by Martin (2002) who performed his study to evaluate the retrieval of long pulp stone in maxillary molars. He suggested that, the common etiologic factors implicated with pulp stone formation include pulp degeneration, age, circulatory disturbance, orthodontic tooth movement, long standing irritants such as caries, deep filling and chronic pulp inflammation. The study was carried out by Horsley et al., (2009) on prevalence of pulp stones in a Turkish population reported that subjects older than age 60 years had significantly higher prevalence of pulp stones in compared to younger age groups. 
Condensation of collagen fibers, dilatation and congestion of blood vessels with area of hemorrhage were observed. Similar findings were also demonstrated by Moule and Barthold (1995) that with advancing age, the density and thickness of the collagen fibers grows as well as fibrosis and irregular calcification appear .

Regarding the histological results of group III (old age rats injected by stem cells) revealed nearly normal histological structure as there were reorganization of pulp cells surrounded by loosely arranged collagen fiber and thin walled normal sized blood vessels. Considerable research is underway exploring many ways that stem cells can be used to restore normal function to damaged, aged and diseased tissues. (Caplan and Dennis 2006) and Meirelles el al., (2009) demonstrated that MSCs produce and release various growth factors and cytokines including anti-apoptotic, immunomodulatory, supportive, angiogenic and chemoattractic factors. These studies indicated that MSCs are promising tools for the treatment of different types of tissue damages, because they secrete a multitude of bioactive molecules that ultimately lead to reformation and regeneration of injured tissues. It has been proposed that the ability of MSCs to secrete a variety of factors that change tissue microenvironment functionally is more important than their trans-differentiation ability in affecting tissue regeneration (Togel etal., 2007).

In old age rats there were dilated and congested blood vessels, while in stem cells injected rats, the blood vessel were not congested and of normal size. This might be due to the angiogenic support provided by MSC, that can be considered one more supportive effect, since the re-establishment of the blood supply is fundamental for recovery of damaged tissues. The pro-angiogenic effect of MSC have been demonstrated in several studies in vitro and in vivo (Kinnaird et al., 2004 and Hung et al., 2007).
One of most important stimulating factors to mesenchymal stem cells is the presence of hypoxia. Interstitial tissue damage is often associated with activation of the coagulation cascade, resulting in areas of hypoxia. It is known that reduction in oxygen tension in a variety of tissues leads to activation of the hypoxia inducible factor (HIF$1 \alpha$ ), which induces transcription of angiogenic genes such as vascular endothelial growth factor (VEGF) (Imtiyaz and Simon 2010) and Hawkins et al., (2013) as well as the MSC chemoattractant stromal cell-derived factor 1 (SDF-1) Ceradini et al., (2004). Once MSC migrate to areas of hypoxia, it has been demonstrated that production of various therapeutic paracrine mediators is increased. Several groups have demonstrated the relevance of hypoxia to MSC growth factor production in vitro. For example, exposure of bone marrow (BM)MSC to 24 hours of hypoxia ( $1 \%$ oxygen) resulted in marked induction of VEGF, Fibroblast growth factor 2 (FGF-2), Hepatocyte growth factor (HGF), and Insulin like growth factor 1 (IGF-1) production, in an NF-kappa $\beta$ dependent manner (Crisostomo et al, 2007).

Immunohistochemical demonstration of proliferation related markers is an effective method for understanding the proliferative potential of cells. The most important used cell proliferation marker, recognized nuclear antigens as associated with all the phases of the cell-cycle expect G0 is Ki67. In our experiment. the immunohistochemical results revealed that, group I (control group) showed mild to moderate expression of Ki67 in nuclei of odontoblasts and endothelium lining of the blood vessels while group II (aged group) showed nearly negative expression of Ki67. These result were in agreement with the results obtained by Seki and Arai, (1995) who found that lower rate of cell proliferation due to considerable age manifested as very week immunostaainig to Ki67. As regarding as group III (aged group injected with mesenchymal stem cells) revealed positive immunoreactivity 
which nearly the same immunoexpression of Ki67 as control group which indicated stimulation of cell proliferation by injection of MSC. These results were explained by recent studies which showed that, there is increasing expressions of post survival factors as postsurvival kinase and protein kinase $B$ in injected cells (Morigi, et al., 2004), growth factors as IGf, VEGf and HGF expression which inhibit apoptosis and stimulate cell proliferation (Imberti et al., 2007) this dynamic permits high cell turn over, renewing damaged cells and decresing cell death thus restoring normal tissue phsiology.

\section{CONCLUSION}

The most important finding of this study is that BM-derived MSCs delivered to old rats through an intravenous route provided improved histological features of the pulp as compared with the old group infused with saline intravenously, so it played an effective role in age related changes. As well as, BM-derived MSCs also had a positive proliferating effect as revealed by the enhanced expression of Ki67.

\section{REFERENCES}

- Bratu D., Românu M., Aparatul Dento-Maxilar. Date de morfologie fuuncpionalã clinicã, Ed. Helicon,Timioara, Pain 1999;81:67-75.

- Murray PE, Stanley HR, Matthews JB, et al. Age related dontometric changes of human teeth. Oral Surg Oral Med Oral Pathol Oral Radio Endod 2002;96:474-82.

- Ikawa M, Komatsu H, Ikawa K, et al.Age-related changes in the human pulpal blood flow measured by laser Doppler flowmetry. Dent Traumatol 2003;19:36-40.

- $\quad$ Kress B, Buhl Y, Hahnel S, et al. Age- and tooth-related pulp cavity signal intensity changes in healthy teeth: a comparative magnetic resonance imaging analysis. Oral Surg Oral Med Oral Pathol Oral Radiol Endod 2007;103:134-7.

- Weissman IL. Stem cells - scientific, medical, and political issues. New England Journal of Medicine 2002;346: 1576-9.
- Prockop DJ: Marrow stromal cells as stem cells for nonhematopoietic tissues. Science 1997, 276(5309): 71-74.

- Friedenstein AJ,Petrakova KV,Kurolesova AI,Frolova GP: Heterotopic transplants of bone marrow. Transplantation 1968, 6(2):230-247.

- Zannettino ACW, Paton S, Arthur A, Khor F, Itescu S, Gimble JM, Gronthos S:Multipotential human adiposederived stromal stem cells exhibit a perivascular phenotype in vitro and in vivo. J Cell Physiol 2008, 214(2):413-421.

- Hoogduijn MJ, Crop MJ, Peeters AMA, Van Osch GJV, Balk AHM, Ijzermans JNM, Baan CC: Human heart, spleen, and perirenal fat-derived mesenchymal stem cells have immunomodulatory capacities. Stem Cells Dev 2007, 16(4):597-604.

- Jo YY, Lee HJ, Kook SY, Choung HW, Park JY, Chung JH, Choung PH: Isolation and characterization of postnatal stem cells from human dental tissues. Tissue Eng 2007, 13(4):767-773.

- He Q, Wan C, Li G: Concise review: multipotent mesenchymal stromal cells in blood. Stem cells (Dayton, Ohio) 2007, 25(1):69-77.

- Hida N, Nishiyama N, Miyoshi S, Kira S, Segawa K, Uyama T, Umezawa A: Novel cardiac precursor-like cells from human menstrual blood-derived mesenchymal cells. Stem cells 2008,26(7):1695-1704.

- Patel AN, Park E, Kuzman M, Benetti F, Silva FJ, Allickson JG: Multipotent menstrual blood stromal stem cells: isolation, haracterization, and differentiation. Cell transplant 2008, 17(3):303-311.

- $\quad$ Yang ZX, Han Z-B, Ji YR, Wang YW, Liang L, Chi Y, Han ZC: CD106 identifies a subpopulation of mesenchymal stem cells with unique immunomodulatory properties. PloS one 2013, 8(3):e59354

- Caplan AI. Mesenchymal stem cells and gene therapy. Clin Orthop. 2000;379(suppl):S67-S70.

- Colter DC, Sekiya I, Prockop DJ. Identification of a subpopulation of rapidly self-renewing and multipotential adult stem cells in colonies of human marrow stromal cells. Proc Natl Acad Sci U S A. 2001;98:7841-7845.

- Javazon E, Colter DC, Schwarz EJ, et al. Rat marrow stromal cells are more sensitive to plating density and expand more rapidly from single-cell derived colonies than human marrow stromal cells. Stem Cells. 2001;19:219-225. 
- Sekiya I, Larson BL, Smith JR, et al. Expansion of human adult stem cells from bone marrow stroma: conditions that maximize the yields of early progenitors and evaluate their quality. Stem Cells. 2002;20:539-534.

- Couzin, J.: Clinical trials. A shot of bone marrow can help the heart. Science 2006; 313, 1715-1716

- Lagasse, E., Connors, H., Al-Dhalimy, M., Reitsma, M., Dohse, M., Osborne, L., Wang, X., Finegold, M., Weissman, I.L., and Grompe, M.: Purified hematopoietic stem cells can differentiate into hepatocytes in vivo. Nat. Med. 2000; 6, 1229-1234.

- $\quad$ Nishida, M., Fujimoto, S., Toiyama, K., Sato, H., and Hamaoka, K. Effect of hematopoietic cytokines on renal function in cisplatin-induced ARF in mice. Biochem. Biophys. Res. Commun. 2004; 324, 341-347.

- Jäger M, Jelinek E, Wess K, et al. Bone marrow concentrate: a novel strategy for bone defect treatment. Curr Stem Cell Res Ther. 2009; 4:34-43.

- Pittenger MF, Mosca JD, Mcintosh KR. Humanmesenchymal stem cells for cartilage, bone, fat and stroma. Curr Top Microbiol Immunol., 2000; 251: 3-11.

- Guo, W.; Wang, H.; Zou, S.; Gu, M.; Watanabe, M.; Wei, F.; Dubner, R.; Huang, G. and Ren, K.: Bone Marrow Stromal Cells Produce Long-Term Pain Relief in Rat Models of Persistent Pain. Stem Cells. NIH; 2011; 29(8): 1294-1303. doi:10.1002/stem.667.

- Scholzen T.; and Gerders J. : The Ki67 protein from the known and the unknown. J. Cell Physiol.; 2000;182 (3): 311- 322 .

- Berkovitz BKB, Holland GR, and Moxham BJ : A Colour Atlas and Textbook of Oral Anatomy, Histology and Embryology (second edition). Wolfe Publishing Ltd. 1992.

- Solheim T : Amount of secondary dentin as an indicator of age. Scand. J. Dent. Res. 1992; 100: 193-199

- Martin AP: A Radiographic assessment of the prevalence of pulp stones. Aust Dent J ; 2002; 47:355-56

- Horsley SH, Beckstrom B, Clark SJ, Scheetz JP, Khan Z, Farman AG. Prevalence of carotid and pulp calcifications: a correlation using digital panoramic radiographs. Int J Comput Assist Radiol Surg. 2009;4:169-73.

- Moule A J, Li H, Barthold PM Donor variability in the proliferation of human dental pulp fibroblast.Austral Dent J 1995; $40: 110-114$

- Caplan AI, Dennis JE: Mesenchymal stem cells as trophic mediators. J cell .Biochem 2006, 98(5):1076-1084.
- Meirelles Lda S, Fontes AM, Covas DT, Caplan AI: Mechanisms involved in the therapeutic properties of mesenchymal stem cells. Cytokine Growth Factor Rev 2009, 20:419-427.

- Tögel F, Weiss K, Yang Y, Hu Z, Zhang P, Westenfelder C: Vasculotropic, paracrine actions of infused mesenchymal stem cells are important to the recovery from acute kidney injury. Am J Physiol Renal Physiol 2007, 292(5): 1626-1635

- Imtiyaz HZ, Simon MC: Hypoxia-inducible factors as essential regulators of inflammation. Curr Top Microbiol Immunol 2010, 345:105-120.

- Hawkins KE, Sharp TV, McKay TR: The role of hypoxia in stem cell potency and differentiation. Regen Med 2013 , 8(6):771-782

- Ceradini DJ, Kulkarni AR, Callaghan MJ, Tepper OM, Bastidas N, Kleinman ME, Gurtner GC: Progenitor cell trafficking is regulated by hypoxic gradients through HIF-1 induction of SDF-1. Nat Med 2004, 10(8):858-864.

- Crisostomo PR, Wang Y, Markel TA, Wang M, Lahm T, Meldrum DR: Human mesenchymal stem cells stimulated by TNF-alpha, LPS, or hypoxia produce growth factors by an NF kappa B- but not JNK-dependent mechanism. Am J Physiol Cell Physiol 2008, 294(3):C675-C682. doi:10.1152/ajpcell.00437.2007.

- $\quad$ Seki T, Arai Y. Age-related production of new granule cells in the adult dentate gyrus. Neuroreport 1995;6:2479_ 82.

- Imberti, B., Morigi, M., Tomasoni, S., Rota, C., Corna, D., Longaretti, L., et al. (2007): Insulin-like growth factor-1 sustain stem cell mediated renal repair. J Am Soc Nephrol; 18 (11):2921-8

- Morigi, M., Imberti, B., Zoja, C., Corna, D., Tomasoni, S., Abbate, M., et al.: Mesenchymal stem cells are renotropic, helping to repair the kidney and improve function in acute renal failure. J Am Soc Nephrol.; 2004; 15(7):1794-804.

- Hung, S.C., Pochampally, R.R., Chen, S.C., Hsu, S.C., Prockop, D.J.: Angiogenic effects of human multipotent stromal cell conditioned medium activate the PI3K-AKt pathway in hypoxic endothelial cells to inhibit apoptosis, increae survival and stimulate angiogenesis. Stem Cells.; 2007; 25(9):2363-70.

- $\quad$ Kinnaird, T., Stabile, E., Burnett, M.S., Shou M., Lee, C.W., Barr, S., et al.: Local delivery of marrow derived stromal cells augments collateral perfusion through paracrine mechanisms. Circulation.; 2004; 109(12):1543-9. 